\title{
OPEN A novel synthetic microtubule inhibitor exerts antiproliferative effects in multidrug resistant cancer cells and cancer stem cells
}

\author{
Mina Park ${ }^{1,4}$, Jee Won Hwang ${ }^{1,4}$, Yena Cho ${ }^{1}$, Saegun Kim², Sang Hoon Han ${ }^{2}$, Jinsuh Yu ${ }^{1}$, \\ Sojung $\mathrm{Ha}^{1}$, Woo-Young $\mathrm{Kim}^{1}$, Su-Nam Kim${ }^{3}$, In Su Kim ${ }^{2 \bowtie}$ \& Yong Kee Kim ${ }^{1 \bowtie}$
}

The success of cancer chemotherapy is limited by multidrug resistance (MDR), which is mainly caused by $\mathrm{P}$-glycoprotein (P-gp) overexpression. In the present study, we describe a novel microtubule inhibitor, 5-(N-methylmaleimid-3-yl)-chromone (SPC-160002), that can be used to overcome MDR. A synthetic chromone derivative, SPC-160002, showed a broad spectrum of anti-proliferative effects on various human cancer cells without affecting $P$-gp expression and its drug efflux function. Treatment with SPC-160002 arrested the cell cycle at the $M$ phase, as evidenced using fluorescence-activated cell sorting analysis, and increased the levels of mitotic marker proteins, including cyclin B, pS10-H3, and chromosomal passenger complex. This mitotic arrest by SPC-160002 was mediated by promoting and stabilizing microtubule polymerization, similar to the mechanism observed in case of taxane-based drugs. Furthermore, SPC-160002 suppressed the growth and sphere-forming activity of cancer stem cells. Our data herein strongly suggest that SPC-160002, a novel microtubule inhibitor, can be used to overcome MDR and can serve as an attractive candidate for anticancer drugs.

Microtubules, a principal component of the cytoskeleton, are composed of $\alpha$-/ $\beta$-tubulin heterodimers that play fundamental roles in mitosis, intracellular trafficking, and cellular structure ${ }^{1,2}$. During mitosis, the dynamic polymerization/depolymerization of spindle microtubules makes dividing cells sensitive to microtubule inhibitors (MTIs) ${ }^{3}$. MTIs are classified into two main groups: microtubule-destabilizing agents (such as vinblastine, colchicine, and combretastatin-A4) and microtubule-stabilizing agents (such as taxanes and epothilones) ${ }^{4}$. These microtubule-targeting agents have been broadly used against many solid and hematologic tumors; however, their clinical success is still largely determined by drug resistance ${ }^{3,5}$. In fact, an MTI, ixabepilone (a derivative of epothilone), which is capable of overcoming drug resistance, has been developed and approved by the FDA ${ }^{6,7}$.

Multidrug resistance (MDR), mainly caused by increased expression of cell-membrane ATP-binding cassette (ABC) transporters, is a crucial obstacle to cancer chemotherapy ${ }^{8-10}$. P-Glycoprotein (P-gp), also known as multidrug resistance protein 1 (MDR1 or ABCB1), acts as a major efflux pump for cytotoxic drugs, thus reducing intracellular drug concentrations $\mathrm{s}^{11,12}$. Overexpression of P-gp is linked to MDR in many human cancer cells, including colon, kidney, adrenal, pancreas, and liver cancer cells ${ }^{9,12,13}$. P-gp has a broad spectrum of substrates, including topoisomerase inhibitors (i.e., etoposide and doxorubicin) ${ }^{14}$, microtubule-targeted drugs (i.e., vinblastine and paclitaxel $)^{15}$, tyrosine kinase inhibitors (i.e., gefitinib and sunitinib), lipids, steroids, xenobiotics, peptides, and glucocorticoids ${ }^{16}$. Therefore, the development of a chemotherapeutic strategy to overcome MDR remains a major challenge in the treatment of cancer.

Chromones (4H-chomen-4-ones) and xanthones ( $9 H$-xanthen-9-ones) are oxygen-containing heterocyclic scaffolds that are widely distributed in nature and are known to have diverse biological activities, including antitumor, anti-microbial, anti-viral, anti-inflammatory, and anti-oxidant activities ${ }^{17-19}$. In particular, the bi- and tricyclic backbones in chromones and xanthones also exhibit biological activities, which differ depending on the type and/or location of the substituents ${ }^{17-19}$. Based on this variability of chromone and xanthone, a library of synthetic analogs of chromones and xanthones is being prepared to develop new bioactive agents ${ }^{20}$. In this

${ }^{1}$ Research Institute of Pharmaceutical Sciences, College of Pharmacy, Sookmyung Women's University, Seoul 04310, Republic of Korea. ${ }^{2}$ School of Pharmacy, Sungkyunkwan University, Suwon 16419, Republic of Korea. ${ }^{3}$ Natural Product Research Institute, Korea Institute of Science and Technology, Gangneung 25451, Republic of Korea. ${ }^{4}$ These authors contributed equally: Mina Park and Jee Won Hwang. ${ }^{\square}$ email: insukim@ skku.edu; yksnbk@sookmyung.ac.kr 
a<smiles>CN1C(=O)CC(c2cccc3occc(=O)c23)C1=O</smiles>

SPC-160001<smiles>CN1C(=O)C=C(c2cccc3occc(=O)c23)C1=O</smiles>

SPC-160002<smiles>CN1C(=O)C=C(c2cccc3oc4ccccc4c(=O)c23)C1=O</smiles>

SPC-160003<smiles>O=C1C=C(c2cccc3occc(=O)c23)C(=O)N1</smiles>

SPC-160004<smiles>O=C1CC(c2cccc3occc(=O)c23)C(=O)N1</smiles>

SPC-160005 b

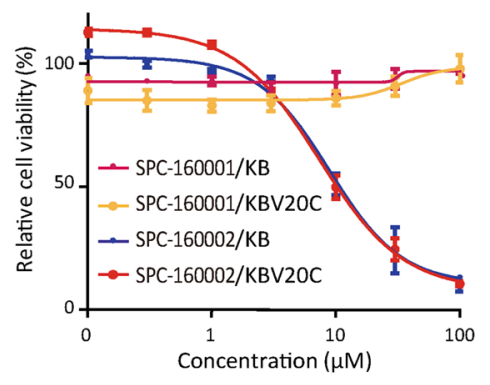

c

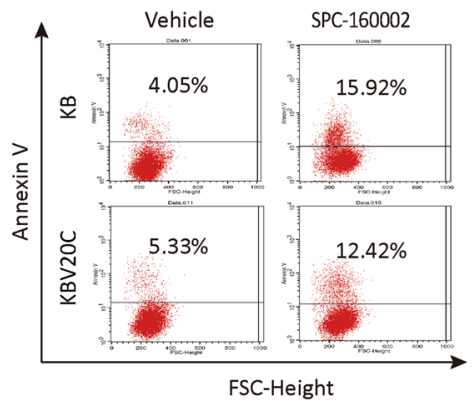

d

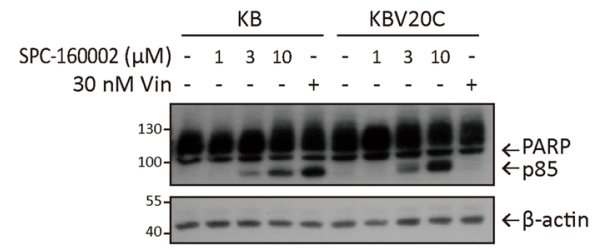

Figure 1. Maleimide-containing chromones inhibit proliferation of MDR cancer cells. (a) Structure of chromone or xanthone derivatives. SPC-160001: 1-methyl-3-(4-oxo-4H-chromen-5-yl)pyrrolidine-2,5-dione, SPC-160002: 1-methyl-3-(4-oxo-4H-chromen-5-yl)-1H-pyrrole-2,5-dione, SPC-160003: 1-methyl-3-(9-oxo9H-xanthen-1-yl)-1H-pyrrole-2,5-dione, SPC-160004: 3-(4-oxo-4H-chromen-5-yl)-1H-pyrrole-2,5-dione, SPC-160005: 3-(4-oxo-4H-chromen-5-yl)pyrrolidine-2,5-dione. (b) The cytotoxicity of chromone and xanthone derivatives in KB and KBV20C cells was determined using MTT assay (48 h). Data is presented as mean \pm SD (standard deviation, $\mathrm{n}=3$ ). (c) KB and KBV20C cells were treated with SPC-160002 $(10 \mu \mathrm{M})$ for $24 \mathrm{~h}$, followed by measurement of Annexin-V positive cells using flow cytometry. (d) Whole cell lysate from SPC-160002 or vincristine-treated cells $(24 \mathrm{~h})$ was subjected to immunoblotting.

\begin{tabular}{|l|l|l|}
\hline & \multicolumn{2}{|l|}{ IC $_{50}(\mu \mathrm{M})$} \\
\cline { 2 - 3 } & KB & KBV20C \\
\hline SPC-160001 & $>100$ & $>100$ \\
\hline SPC-160002 & $10.3 \pm 0.58$ & $10.7 \pm 1.03$ \\
\hline SPC-160003 & $29.9 \pm 4.12$ & $33.5 \pm 1.11$ \\
\hline SPC-160004 & $6.59 \pm 1.58$ & $9.15 \pm 1.67$ \\
\hline SPC-160005 & $>100$ & $>100$ \\
\hline Paclitaxel (nM) & $2.66 \pm 1.29$ & $>1000$ \\
\hline
\end{tabular}

Table 1. Cytotoxicity of maleimide-containing chomones and xanthone. $\mathrm{IC}_{50}$ values of chromone and xanthone derivatives were calculated based on MTT assay at $48 \mathrm{~h}$ in KB and KBV20C cells. Data are mean \pm SD $(\mathrm{n}=3)$.

study, we describe the molecular mechanism by which 5-(N-methylmaleimid-3-yl)-chromone (SPC-160002) inhibits the growth of various human cancer cells, including MDR cancer cells and cancer stem cells (CSCs). SPC-160002 suppressed the growth of not only a variety of human cancer cell lines but also P-gp-overexpressing MDR cancer cells, without affecting the expression and function of P-gp. These anti-proliferative effects were found to be mainly driven by mitotic arrest, resulting from stabilization of microtubule polymerization. In addition, SPC-160002 strongly suppressed the survival and sphere-forming activity of CSCs. Based on the established experimental results, we suggest the therapeutic potential of SPC-160002 as a novel microtubule-targeting drug that can overcome drug resistance.

\section{Results}

Maleimide-containing chromone derivatives show anti-proliferative effects in MDR cancer cells. To develop a novel anticancer drug that can overcome MDR, we examined the anti-proliferative effects of several chromone and xanthone derivatives (Fig. 1a) using P-gp-overexpressing KBV20C cells. The KBV20C cells, derived from $\mathrm{KB}^{21,22}$ were evaluated to have more than 300 times resistance to paclitaxel compared to its parental KB cells (Table 1). Among them, maleimide-containing chromones and xanthones (SPC-160002, SPC160003, and SPC-160004) showed anti-proliferative effects in both KBV20C cells and their parental KB cells, while succinimide-containing compounds (SPC-160001 and SPC-160005) had no growth inhibition effect until 


\begin{tabular}{|l|l|r|}
\hline & Cell lines & IC $_{\mathbf{5 0}}(\boldsymbol{\mu M})$ \\
\hline \multirow{2}{*}{ Lung cancer } & H226B & $5.82 \pm 1.93$ \\
\cline { 2 - 3 } & A549 & $14.29 \pm 3.25$ \\
\hline \multirow{2}{*}{ Prostate cancer } & LNCaP & $3.74 \pm 2.04$ \\
\cline { 2 - 3 } Breast cancer & DU145 & $13.33 \pm 1.22$ \\
\hline \multirow{2}{*}{ Colorectal cancer } & SK-BR-3 & $3.52 \pm 1.34$ \\
\cline { 2 - 3 } & MCF7 & $26.89 \pm 0.86$ \\
\cline { 2 - 3 } & HCD-1 & $11.52 \pm 1.58$ \\
\hline \multirow{2}{*}{ Glioblastoma } & A172 & $11.6 \pm 1.68$ \\
\cline { 2 - 3 } & U87MG & $10.67 \pm 2.08$ \\
\hline Liver cancer & HepG2 & $7.04 \pm 1.70$ \\
\hline
\end{tabular}

Table 2. Anti-proliferative effects of SPC-160002 on various human cancer cells. $\mathrm{IC}_{50}$ values of SPC-160002 were calculated for each cell line using MTT assay. Data are mean \pm SD $(n=3)$.

a concentration of $100 \mu \mathrm{M}$ in both the cells (Table 1 and Fig. 1b), indicating that the maleimide substituent is essential for the growth-inhibitory effect. Upon comparing the effects of SPC-160002, SPC-160003 and SPC160004 , we found that the structure of chromone had stronger activity than that of xanthone (Table 1). However, there was no difference in the anti-proliferative effects of $N$-methyl-substituted maleimide (SPC-160002) and (NH)-free-maleimide (SPC-160004) (Table 1). Altogether these results suggest that the chromones containing maleimide or 5- $N$-methylmaleimide exert anti-proliferative effects against MDR cancer cells. However, their potencies are much weaker than that of paclitaxel (Table 1).

In this study, we also investigated the molecular mechanism by which SPC-160002 [5-( $N$-methylmaleimid3-yl)-chromone] exerts anti-proliferative activity in MDR cancer cells. As shown in Table 2, SPC-160002 showed a broad spectrum of anti-proliferative effects on various human cancer cells. Based on the cytotoxicity of SPC160002, we investigated whether SPC-160002 could induce apoptosis. Treatment of SPC-160002 led to an increase in the Annexin V-positive population in both KB and KBV20C cells (Fig. 1c). The apoptotic potential of SPC160002 was further confirmed by measuring PARP cleavage, as a marker of apoptosis (Fig. 1d). As expected, KBV20C cells were found to be highly resistant to vincristine, thus showing the MDR phenotype of KBV20C cells (Fig. 1d). Taken together, our data show that SPC-160002 has a broad spectrum of anti-proliferative effects on various human cancer cells as well as MDR cancer cells.

SPC-160002 does not affect $P$-gp expression and its drug efflux function. To determine whether SPC-160002 affects the expression or function of P-gp, we first examined the expression levels of P-gp mRNA and protein. As shown in Fig. 2a,b, there were no differences in both mRNA and protein levels between the control and SPC-160002-treated cells. Following that, to investigate whether the efflux function of P-gp is affected by SPC-160002, we measured the intracellular accumulation of rhodamine 123, a well-established substrate of P-gp. Rhodamine 123 was found to be extensively accumulated in KB cells, but not in KBV20C cells (Fig. 2c), re-validating the MDR phenotype of KBV20C cells. There was no change in the accumulation of rhodamine 123 in KBV20C cells upon SPC-160002 treatment, while there was a profound increase upon treatment with a P-gp inhibitor, verapamil (Fig. 2c), which was further confirmed using fluorescence microscopy (Fig. 2d). These results indicate that SPC-160002 does not affect both P-gp expression and its drug efflux function.

SPC-160002 blocks cell cycle progression at the $\mathrm{G}_{2} / \mathrm{M}$ phase. To investigate the molecular mechanisms by which SPC-160002 exerts anti-proliferative activity on cancer cells, we analyzed the cell cycle using flow cytometry. As shown in Fig. 3a,b, treatment with SPC-160002 dose-dependently decreased the proportion of cells in $G_{1}$ phase and increased the proportion of cells in $G_{2} / M$ phase in both $K B$ and KBV20C cells. As expected, vincristine induced $\mathrm{G}_{2} / \mathrm{M}$ arrest in $\mathrm{KB}$ cells, but not in KBV20C cells. To confirm $\mathrm{G}_{2} / \mathrm{M}$ arrest by SPC-160002, we examined the levels of cell cycle-related proteins. SPC-160002 dramatically increased cyclin B1, a key regulator of the $\mathrm{G}_{2} / \mathrm{M}$ transition, but decreased $\mathrm{G}_{1} / \mathrm{S}$-specific cyclin D3 (Fig. 3c). In addition, there was a drastic decrease in the level of pY15-cdk1, an inactive form, indicating that SPC-160002 promotes M phase transition from $\mathrm{G}_{2}$ phase. There was a clear decrease in the levels of the cdk inhibitors, p21 and p27 at $10 \mu \mathrm{M}$ of SPC-160002, similar to the effect seen in case of nocodazole, a well-known mitotic inhibitor. Furthermore, SPC160002 treatment dramatically increased both pS10-H3 and pT3-H3, which are representative histone marks for $\mathrm{M}$ phase (Fig. 3c). It has been well-established that $\mathrm{pS} 10-\mathrm{H} 3$ is mainly generated by Aurora B kinase in chromosomal passenger complex (CPC) during mitosis ${ }^{23}$, and the CPC complex, composed of Aurora B, INCENP, Borealin, and Survivin, is a major regulator of chromosome segregation during mitosis and cytokinesis ${ }^{24-26}$. We thus examined the expression levels of CPC components in the presence of SPC-160002. As expected, SPC160002 treatment dramatically increased the level of all CPC components, Aurora B, Borealin, and Survivin, with only the exception of INCENP. These expression profiles upon SPC-160002 treatment were consistent with those of nocodazole. Altogether, our data support that SPC-160002 is a mitotic inhibitor and causes mitotic arrest of cancer cells. 


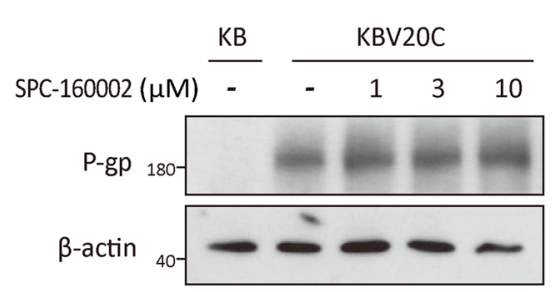

b

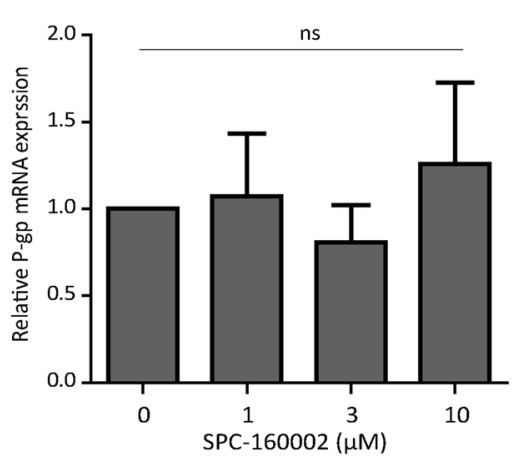

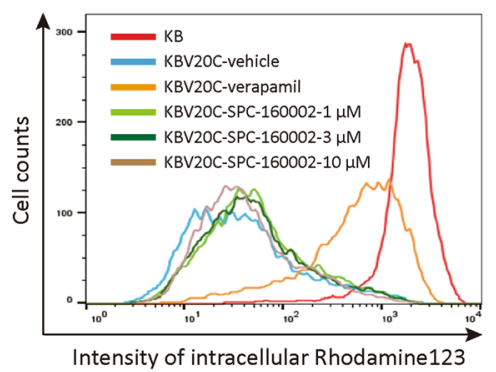

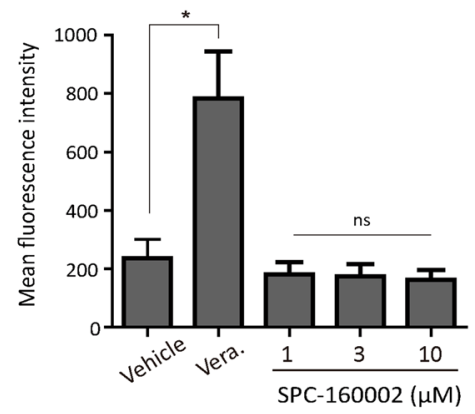

d
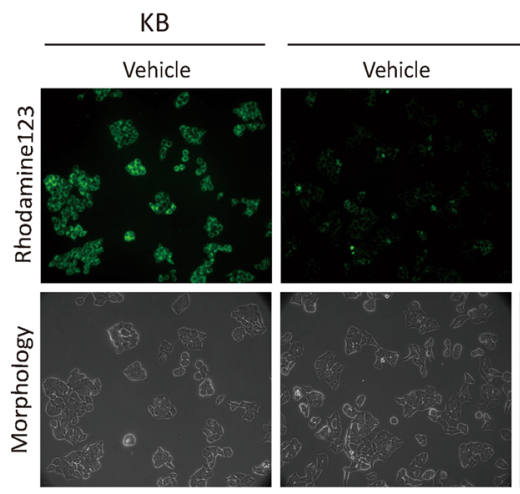

KBV20C SPC-160002

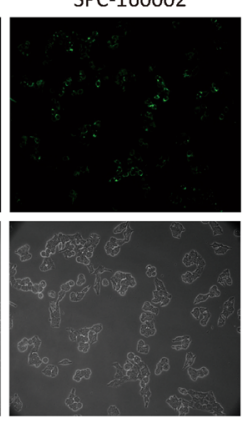

Verapamil
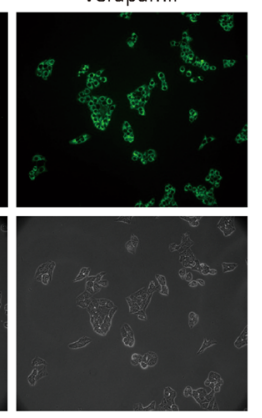

Figure 2. SPC-160002 does not affect P-gp expression and its drug efflux function. (a) The P-gp protein levels in KB and SPC-160002-treated KBV20C cells (24 h) were analyzed. (b) KBV20C cells were treated with SPC160002 for $24 \mathrm{~h}$, followed by determination of P-gp mRNA using quantitative RT PCR. Data is presented as mean \pm SD $(\mathrm{n}=3)$. (c, d) KB and KBV20C cells were treated with DMSO (vehicle), $10 \mu \mathrm{M}$ verapamil (vera) or SPC-160002 for $1 \mathrm{~h}$ followed by $10 \mu \mathrm{M}$ rhodamine 123 for $3 \mathrm{~h}$. Intracellular rhodamine 123 was measured using (c) flow cytometry or (d) fluorescence microscopy. Representative image of SPC-160002-treated group $(10 \mu \mathrm{M})$ is shown. Error bars represent $\mathrm{SD}(\mathrm{n}=3){ }^{*} \mathrm{p}<0.05$.

SPC-160002 blocks mitotic exit in cell cycle. To explore the molecular mechanism underlying M phase arrest by SPC-160002, we analyzed the kinetics of cell cycle progression. KB cells were synchronized at the $\mathrm{G}_{1}-\mathrm{S}$ boundary using double thymidine block (DTB) and then released in the absence or presence of SPC-160002. Six hours after release, most of the control cells moved to the $G_{2} / M$ phase and then went back to the $G_{1}$ phase after $9 \mathrm{~h}$ of release, while only $20 \%$ of SPC-160002-treated cells were in the $\mathrm{G}_{2} / \mathrm{M}$ phase after $6 \mathrm{~h}$ of release; the cells in the $\mathrm{G}_{2} / \mathrm{M}$ phase very slowly increased and accumulated after $12 \mathrm{~h}$ of release (Supplementary Figs. 1a and $4 \mathrm{a}$ ). These results indicate that SPC-160002 retarded the cell cycle progression from $G_{1}$ to $M$ phase and blocked the exit from M phase, leading to mitotic arrest. To further evaluate the blockade of M phase exit by SPC-160002, we synchronized cells at pro-metaphase using thymidine-nocodazole (TN) block and then released them with or without SPC-160002 treatment. In the control group, most of the cells moved to the $\mathrm{G}_{1}$ phase within $2 \mathrm{~h}$, whereas SPC-160002-treated cells remained at the M phase at $6 \mathrm{~h}$ (Supplementary Figs. $1 \mathrm{~b}$ and $4 \mathrm{~b}$ ), further supporting the blockade of mitotic exit by SPC-160002. Next, we examined the changes in the levels of cell cycle markers using cell lysates corresponding to flow cytometry experiments. There was a transient increase in the levels of pS10-H3, pT3-H3, and CPC in the control cells at the M phase, followed by a rapid decrease at the G1 phase, which depends on cell cycle progression (Fig. 4c). However, the levels in SPC-160002-treated cells were sustained after $12 \mathrm{~h}$ of release (Fig. $4 \mathrm{c}$ ). Furthermore, similar results were obtained from the TN-release experiment; the levels of pS10-H3, pT3-H3, and CPC in the SPC-160002 treated cells were higher than those in the control cells (Fig. 4d). These results were in good accordance with the previous results of cell cycle progression (Supplementary Fig. 1a,b and 4a,b), strongly supporting that SPC-160002 blocks mitotic exit in the cell cycle, and subsequently, causes mitotic arrest.

SPC-160002 promotes and stabilizes tubulin polymerization. Given the mitotic arrest by SPC160002, we performed immunofluorescence staining of microtubules to analyze the effect of SPC-160002 on mitotic morphology. Remarkably, 39\% of SPC-160002-treated cells had a mitotic spindle structure with strong microtubule fluorescence intensity, which was comparable to paclitaxel treated cells (Fig. 5a,b). We then subdivided the cells displaying mitotic morphology according to the mitotic substages (Supplementary Fig. 2). As shown in Fig. 5c, in the presence of SPC-160002, there was a profound increase in the mitotic cell populations in pro-metaphase, but not in anaphase or telophase, similar to the phenotypes of taxane class drugs ${ }^{27,28}$. The association of taxanes with $\beta$-tubulin stabilizes the microtubule structure and consequently suppresses the microtu- 
a

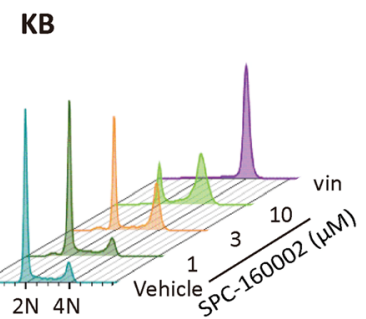

b

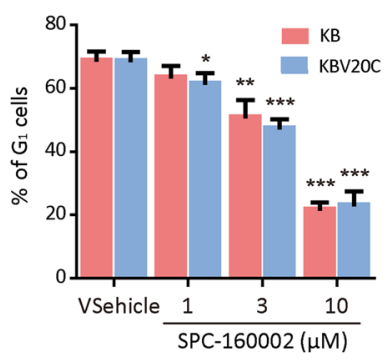

KBV20C

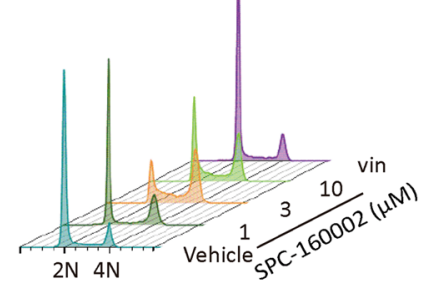

$2 \mathrm{~N} 4 \mathrm{~N}$

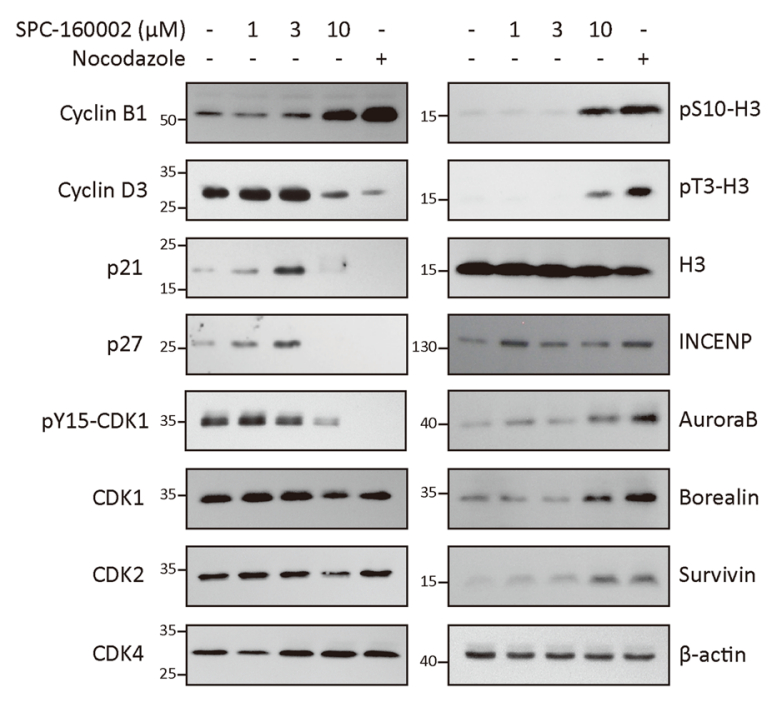

Figure 3. SPC-160002 arrests cell cycle progression at the $\mathrm{G}_{2} / \mathrm{M}$ phase. (a) $\mathrm{KB}$ and $\mathrm{KBV} 20 \mathrm{C}$ cells were treated with DMSO (vehicle), SPC-160002 or $30 \mathrm{nM}$ vincristine (vin) for $24 \mathrm{~h}$ and then stained with PI. DNA contents were analyzed using flow cytometry. (b) Percentage of cells in the $G_{1}$ or $G_{2} / M$ phases in (a) has been expressed as a bar graph. Data from 3 independent experiments were presented as mean $\pm \mathrm{SD} .{ }^{*} p<0.05,{ }^{* *} p<0.01$ and ${ }^{* * *} p<0.001$. (c) KB cells were treated with SPC-160002 or $100 \mathrm{ng} \mathrm{mL}^{-1}$ nocodazole for $24 \mathrm{~h}$ and then the whole cell lysates were subjected to immunoblotting.

bule dynamics, resulting in mitotic arrest ${ }^{27,28}$. To examine the effects of SPC-160002 on tubulin polymerization dynamics, we performed an in vitro microtubule polymerization assay. Purified tubulin was incubated with SPC-160002 and the absorbance at $340 \mathrm{~nm}$ was measured every $30 \mathrm{~s}$ during incubation. Remarkably, we found that SPC-160002 dramatically promoted tubulin polymerization (Fig. 5d), like paclitaxel. Indeed, there was polymerization and stabilization of intracellular microtubule upon SPC-160002 treatment (Fig. 5e). However, the microtubule stabilizing effect of SPC-16002 appears to be much weaker than that of paclitaxel. Altogether, these results strongly suggest that SPC-160002 is a novel microtubule inhibitor that promotes and stabilizes microtubule polymerization.

SPC-160002 inhibits survival and sphere-formation of cancer stem cells. It has been well established that CSCs represent a small population of cells with tumor-initiation potential ${ }^{29,30}$. Because CSCs are resistant to conventional chemotherapeutic agents as well as radiation therapy, and play a role in tumor metastasis and relapse ${ }^{29,30}$, they serve as important targets for the development of novel anticancer drugs. The resistance of CSCs to chemotherapy is mainly due to the overexpression of ABC transporters ${ }^{8,31}$.

We cultured KB cells in the attachment free condition with CSC culture medium. It generated typical CSC spheres (Fig. 6a) and were maintained in multiple passages. The P-gp expression of CSC spheres is higher than that of 2D monolayer cultured cells (Supplementary Fig. 3), which is in good accordance with the observation that the KB-derived CSCs are at least tenfold more resistant to paclitaxel than the bulk culture KB cells (Supplementary Fig. 4). In the presence of SPC-160002, both the proliferation of 2D monolayer cultured KB cells and CSC sphere-forming activity were dramatically inhibited with the similar potency (Fig. $6 \mathrm{~b}, \mathrm{c})$. To further confirm the inhibitory effect of SPC-160002 on the survival of CSCs, specifically, we performed Aldefluor assay which quantify aldehyde dehydrogenase (ALDH, a CSC-predominant enzyme)-positive CSCs. In the presence of SPC-160002, there was a significant reduction in the ALDH-positive cells in the KB-derived CSC spheres (Fig. 6d), suggesting that SPC-160002 effectively eliminates the CSCs in KB cells. To further strengthen the antiCSC-sphere forming activity of SPC-160002, we used U87 glioblastoma CSC model in which the role of P-gp in CSC was well characterized ${ }^{32}$. As expected, SPC-160002 treatment effectively inhibits the population of CSCs in U87 cells (Supplementary Fig. 5).

\section{Discussion}

Several MTIs, including paclitaxel and vincristine, have been used as potent and effective chemotherapeutics for various cancer treatments; however, acquired resistance to these molecules due to MDR serves as a major impediment for successful treatment. Thus, development of microtubule-targeting drugs that can overcome MDR is a major research problem. It has been reported that several chromone compounds have the ability to target microtubules ${ }^{33,34}$; however, there is no evidence whether these anti-microtubule chromones have 
a

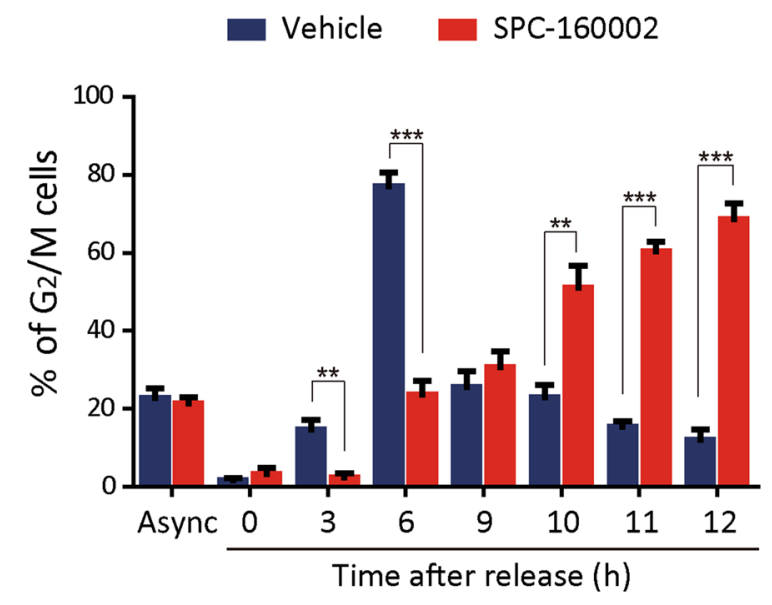

C

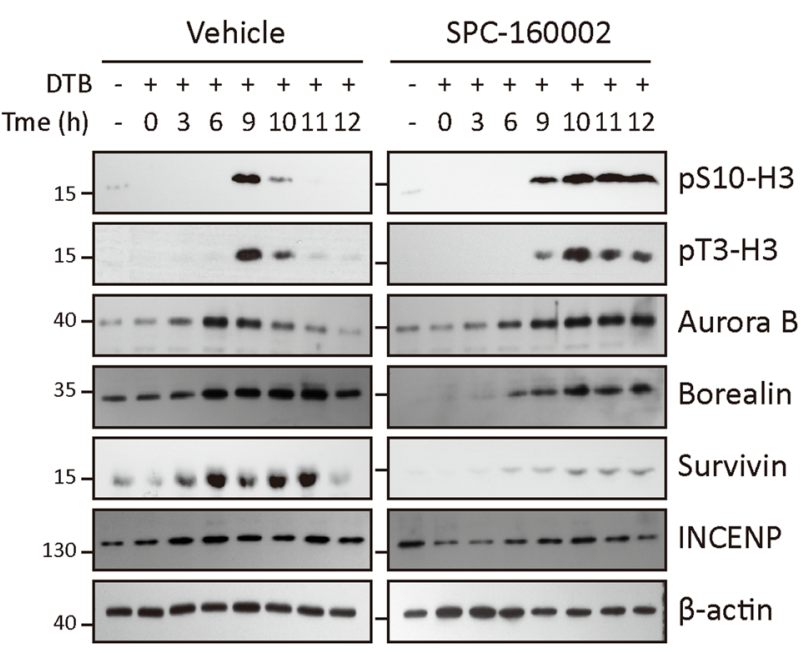

b

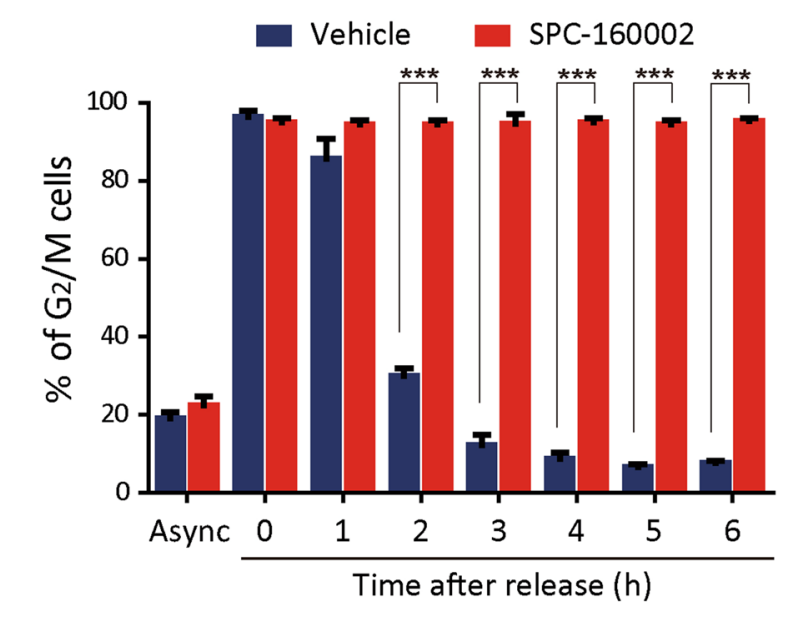

d

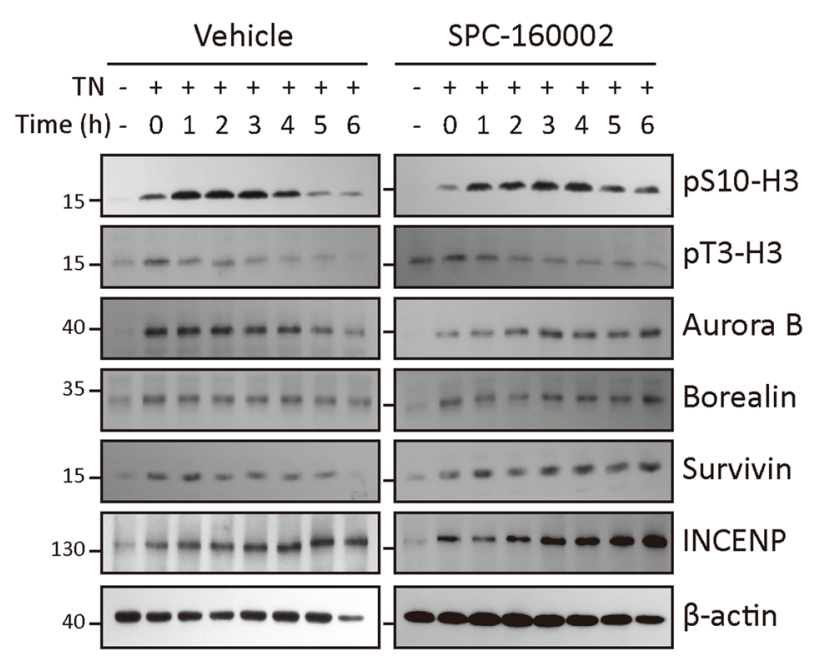

Figure 4. SPC-160002 blocks mitotic exit. (a-d) KB cells were synchronized using DTB (a, c) or TN (b, d) block and then released with or without $10 \mu \mathrm{M}$ SPC-160002 for the indicated times. (a, b) Cells were stained with PI and analyzed using flow cytometry. Percentage of cells in $\mathrm{G}_{2} / \mathrm{M}$ phase has been shown. Error bars indicate SD of three independent replicates. ${ }^{* *} p<0.01$ and ${ }^{* * *} p<0.001$. (c, d) Whole cell lysates corresponding to $(\mathbf{a}, \mathbf{b})$ were examined using immunoblotting.

MDR-overcoming ability. Herein, we describe that SPC-160002 [5-( $N$-methylmaleimid-3-yl)-chromone] is a novel microtubule inhibitor that exerts anti-proliferative effects in both MDR cancer cells and CSCs. SPC-160002 is effective in human cancer cells derived from various tissues; moreover, it effectively inhibits cell growth in MDR cancer cells. It is assumed that SPC-160002 is not a substrate for ABC transporters including P-gp, because it strongly suppresses the proliferation of P-gp-expressing cancer cells, resulting in apoptotic cell death. In addition, it does not affect the expression and drug efflux function of P-gp. Although SPC-160002 has limited selectivity and superiority over MDR cancer cells, it can serve as an attractive candidate for the development of potent anticancer drugs with the ability to overcome MDR. The presence of CSCs in tumor makes them resistant to chemotherapy and radiation therapy, consequently leading to recurrence and metastasis of cancer ${ }^{29,30}$. Although extensive research has been devoted to the development of anticancer drugs that target $\mathrm{CSCs}^{29,31}$, the effective treatment of CSCs remains a challenge that needs to be addressed. SPC-160002 inhibits the sphere-forming activity of both KB and U87 glioblastoma cells and decreases the ALDH-positive cells in CSC-like spheres, suggesting the potential of SPC-160002 as a CSC-targeting drug.

Chromones and xanthones are classes of heterocyclic compounds that commonly exist in nature ${ }^{17-19}$. They consist of diverse functional substituents that are implicated in a variety of pharmacological activities, including anti-inflammatory, anti-bacterial, anti-oxidant, and anti-tumor activities. Their numerous biological and pharmacological activities depend on the structural composition of the substituents and several of these derivatives are indeed used as therapeutic agents. Our data show that SPC-160002 stabilizes microtubule structure and induces mitotic arrest, subsequently leading to apoptosis. There are the obvious differences between SPC-160002 and paclitaxel on microtubule stabilization effect (Fig. 5 c,d), which seems to be due to their potency differences. The potency of paclitaxel is over 300 times higher than that of SPC-160002 (Table 1), which is good agreement with 
a

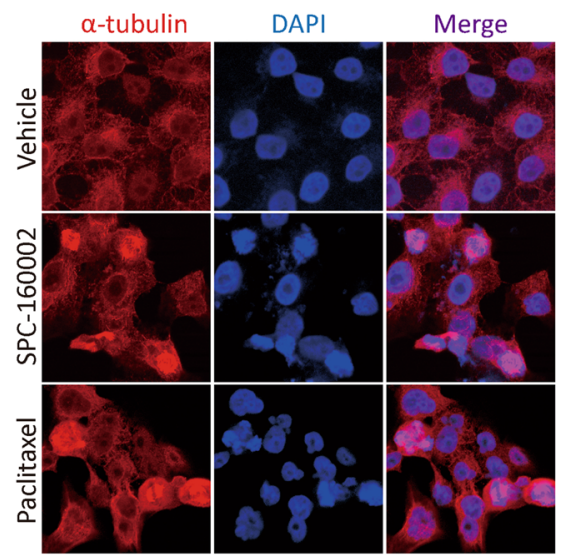

b

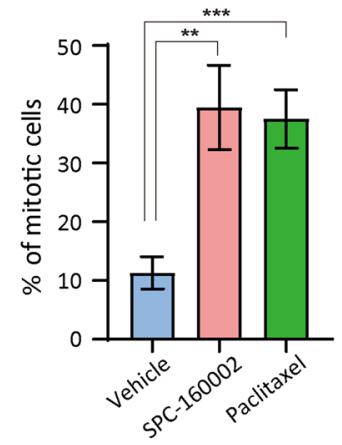

C

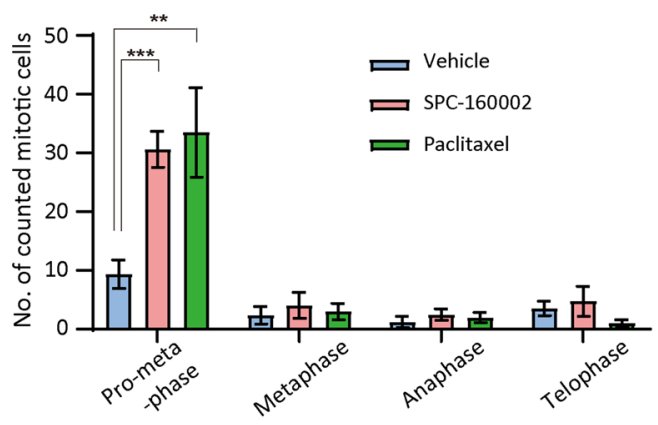

d

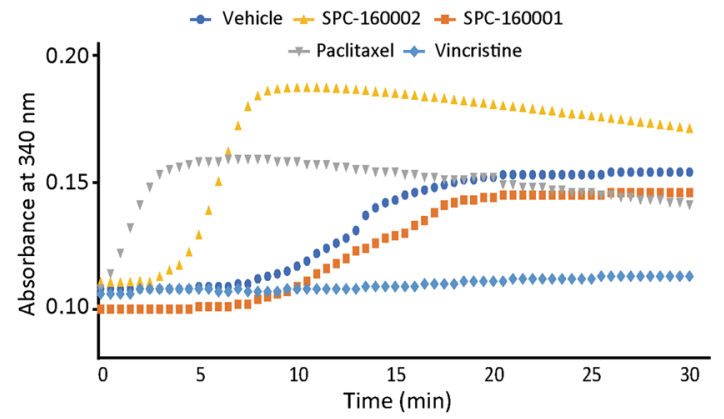

e

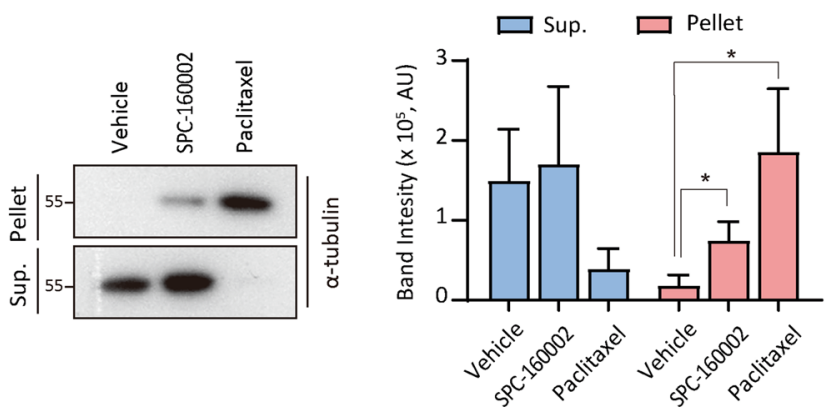

Figure 5. SPC-160002 promotes and stabilizes microtubule polymerization. (a-c) KB cells were treated with DMSO (vehicle), $10 \mu \mathrm{M}$ SPC-160002 or $10 \mathrm{nM}$ paclitaxel for $24 \mathrm{~h}$ and then immunostained with $\alpha$-tubulin. Representative images are shown in (a). (b) Cells displaying mitotic morphology were counted. Error bars represent SD $(n=3)$. (c) The cells counted in (b) were categorized into pro-metaphase, metaphase, anaphase, and telophase. Data from 3 independent experiments were presented as bar chart (mean \pm SD). (d) In vitro tubulin polymerization assay with DMSO (vehicle), $10 \mu \mathrm{M}$ SPC-160002, $10 \mu \mathrm{M}$ SPC-160001, $100 \mathrm{nM}$ paclitaxel, or $30 \mathrm{nM}$ vincristine. (e) KB cells were treated with DMSO (vehicle), $10 \mu \mathrm{M}$ SPC-160002 or $100 \mathrm{nM}$ paclitaxel for $24 \mathrm{~h}$. Supernatant (sup) and pellet of cell lysate were examined using immunoblotting with a $\beta$-tubulin antibody. Data obtained from three replicated experiments were quantified and graphed. ${ }^{\star} p<0.05,{ }^{* *} p<0.01$, and ${ }^{* * *} p<0.001$

the observations that microtubule stabilizing effect of paclitaxel is higher than that of SPC-16002 (Fig. 5c,d). The microtubule-stabilizing effect of SPC-160002 appears to be due to the maleimide group, because the succinimidecontaining compounds (SPC-160001 and SPC-160005) did not show any such effect, while similar effects were seen in maleimide-containing compounds (SPC-160003 and SPC-160004). Although we cannot currently explain how the maleimide group contributes to microtubule stabilization, it is possible that the maleimide group interacts with microtubules by the Michael-type addition reaction. Tubulin is a sulfhydryl-rich heterodimer with 20 cysteine residues, which reacts with sulfhydryl-directed reagents, thus regulating microtubule polymerization or depolymerization ${ }^{35,36}$. This explanation is further supported by our preliminary observation that SPC-160002 blocks irreversibly cell proliferation (Supplementary Fig. 6). Since our SPC compounds are less potent or effective than paclitaxel, their pharmacological properties are needed to be improved for further developing these compounds as anti-cancer drugs. Further research, including the number, position, or variation of the maleimide substituent, is needed to improve their potencies or efficacies. Altogether, we suggest that SPC-160002 might be an attractive lead molecule for further development of chemotherapeutics with the ability to overcome MDR.

\section{Materials and methods}

Typical procedure for the reaction of chromone (SPC-160001 and SPC-160005). 1-Methyl$1 \mathrm{H}$-pyrrole-2,5-dione (44.4 mg, $0.4 \mathrm{mmol}, 200 \mathrm{~mol} \%)$ and DCE $(1 \mathrm{~mL})$ were added to an oven-dried sealed tube charged with $4 H$-chromen-4-one (29.2 mg, $0.2 \mathrm{mmol}, 100 \mathrm{~mol} \%)$, [RhCp $\left.{ }^{\star} \mathrm{Cl}_{2}\right]_{2}(3.1 \mathrm{mg}, 0.005 \mathrm{mmol}, 2.5 \mathrm{~mol} \%)$, $\mathrm{AgSbF}_{6}$ (6.8 mg, $0.02 \mathrm{mmol}, 10 \mathrm{~mol} \%$ ), and PivOH (20.4 mg, $\left.0.2 \mathrm{mmol}, 100 \mathrm{~mol} \%\right)$ under air at room temperature. The reaction mixture was stirred for $20 \mathrm{~h}$ at $80^{\circ} \mathrm{C}$, then diluted with EtOAc $(3 \mathrm{~mL})$, and finally concentrated in vacuo. The residue was purified using flash column chromatography (EtOAc $n$-hexanes $=2: 1$ ) to obtain $48.9 \mathrm{mg}$ of SPC-160001 at a yield of 95\%, the structural analysis data for which is shown in the "Supplementary Information". 
a

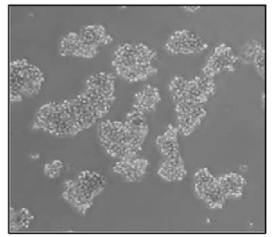

Vehicle

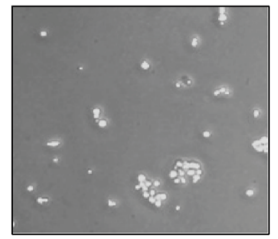

SPC-160002 b

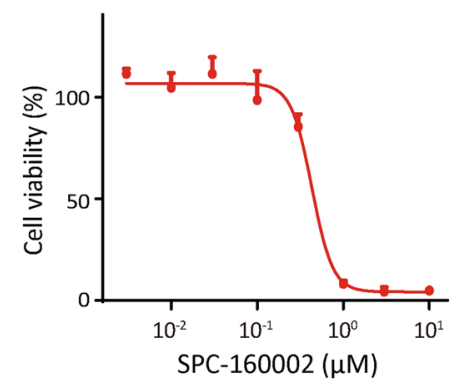

C

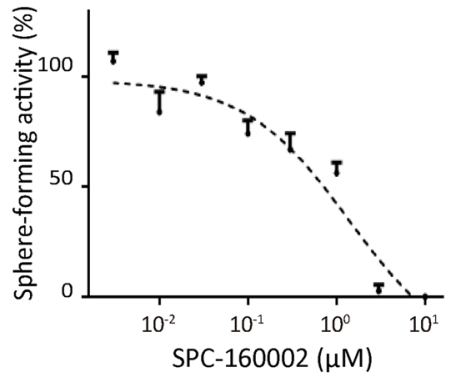

d
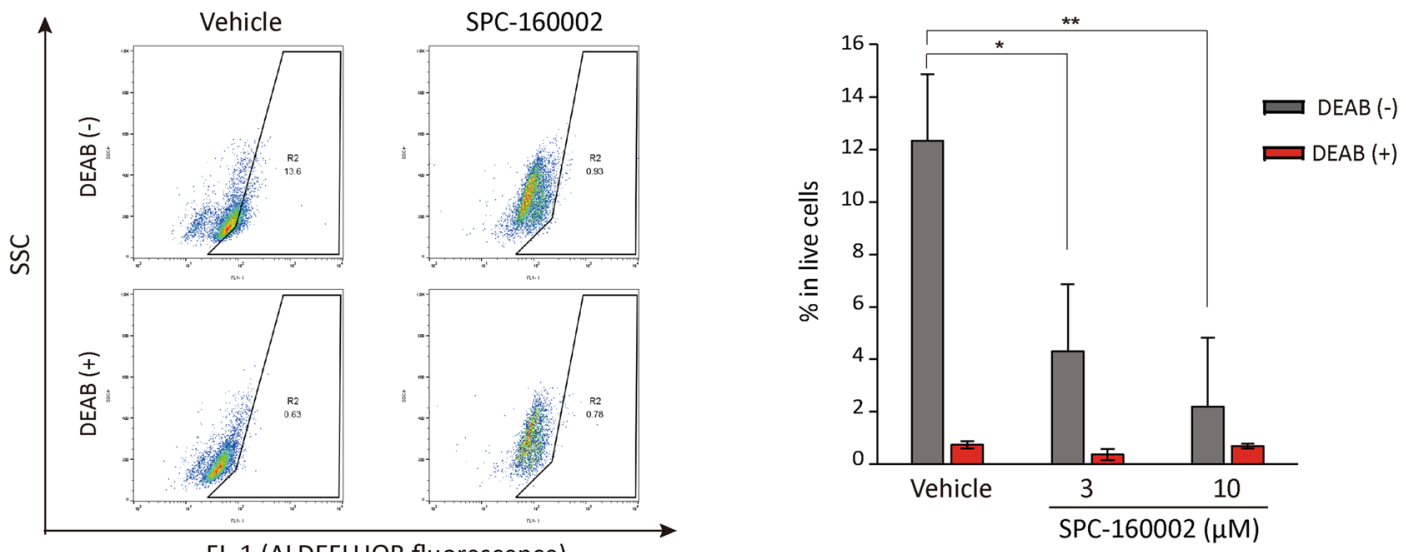

Figure 6. SPC-160002 inhibits survival and sphere-formation ability of CSCs. (a) The KB cells established CSC spheres in CSC enriched culture. (b) The cytotoxicity of KB cells cultured in the attached condition with or without SPC-160002 (4 days) supplemented with 1\% FBS was determined by MTS assay. Error bars represent $\mathrm{SD}(\mathrm{n}=6)$. (b) CSC cultured KB cells were re-seeded in poly-HEMA-coated 96-well plates for 4 days with or without SPC-160002 with CSC medium, followed by counting of the number of spheres ( $\geq 100 \mu \mathrm{m}$ in diameter). Data represent mean \pm SD $(n=4)$. (c) The secondary sphere cells cultured with or without SPC-160002 for $48 \mathrm{~h}$ were dissociated into single cells and then incubated with Aldefluor substrate, with or without DEAB. The Aldefluor-positive cells were detected using flow cytometry. Error bars indicate SD of 3 independent replicates. ${ }^{\star} p<0.05$ and ${ }^{* *} p<0.01$.

Typical procedure for the reaction of chromone and xanthone (SPC-160002, SPC-160003, and SPC-160004). 1-Methyl-1H-pyrrole-2,5-dione (44.4 mg, $0.4 \mathrm{mmol}, 200 \mathrm{~mol} \%)$ and DCE (2 mL) were added to an oven-dried sealed tube charged with $4 H$-chromen-4-one $(29.2 \mathrm{mg}, 0.2 \mathrm{mmol}, 100 \mathrm{~mol} \%)$, [Ru( $p$ cymene $\left.\mathrm{Cl}_{2}\right]_{2}(12.2 \mathrm{mg}, 0.02 \mathrm{mmol}, 10 \mathrm{~mol} \%), \mathrm{AgNTf}_{2}$ (31.0 mg, $0.08 \mathrm{mmol}, 40 \mathrm{~mol} \%$ ), and AgOAc (60.1 mg, $0.6 \mathrm{mmol}, 300 \mathrm{~mol} \%)$ under air at room temperature. The reaction mixture was stirred for $12 \mathrm{~h}$ at $120^{\circ} \mathrm{C}$, then diluted with EtOAc $(5 \mathrm{~mL})$, and finally concentrated in vacuo. The residue was purified using flash column chromatography (EtOAc/ $n$-hexanes $=3: 1$ ) to obtain $43.7 \mathrm{mg}$ of SPC- 160002 at a yield of $86 \%$, the structural analysis data for which is shown in the "Supplementary Information".

Cell culture. Human cancer cell lines used in this study (KB, H226B, A549, LNCaP, DU145, SK-BR-3, MCF7, DLD-1, HCT116, A172, and HepG2) were purchased from American Type Culture Collection (Manassas, VA, USA). The multidrug-resistant cell line KBV20C was derived from $\mathrm{KB}^{21,22}$. KB, KBV20C, H226B, A549, LNCaP, DU145, and DLD-1 cells were grown in RPMI-1640 (HyClone Laboratories, Logan, UT, USA), while SK-BR-3, MCF7, HCT116, A172, and HepG2 cells were grown in DMEM (HyClone Laboratories), both supplemented with $10 \%$ FBS (HyClone Laboratories) and 100 units/mL of penicillin/streptomycin (HyClone Laboratories). KBV20C cells were maintained with $20 \mathrm{nM}$ vincristine in their cell growth medium. Glioblastoma multiform, U87 cells, a kind gift from Dr. Hyunggee Kim (Korea University), were cultured in DMEM/F12 medium (Invitrogen, Waltham, MA). All cells were maintained at $37^{\circ} \mathrm{C}$ under $5 \% \mathrm{CO}_{2}$ in a humidified cell culture incubator.

Chemicals and antibodies. Verapamil, vincristine, and paclitaxel were purchased from Sigma-Aldrich (St. Louis, MO, USA). The commercial antibodies used included anti- $\beta$-actin (sc-47778, dilution of 1:10,000), anti-CDK1 (sc-54, dilution of 1:1000), anti-cyclin B1 (sc-752, dilution of 1:1000), and $\alpha$-tubulin (sc-23948, dilution of 1:5000) antibodies purchased from Santa Cruz Biotechnology (Dallas, TX, USA); anti-phospho-H3-S10 (\#9701, dilution of 1:1000), anti-phospho-CDK1-Y15 (\#4539, dilution of 1:1000), anti-CDK2 (\#2546, dilution of 1:1000), anti-CDK4 (\#12790, dilution of 1:1000), and anti-H3 (\#9715, dilution of 1:5000) antibodies purchased from Cell Signaling Technology (Danvers, MA, USA); anti-INCENP (ab12183, dilution of 1:1000), anti-survivin 
(ab76424, dilution of 1:1000), anti-aurora B (ab2254, dilution of 1:1000), and anti-phospho-H3-T3 (ab78351, dilution of 1:1000) antibodies purchased from Abcam (Cambridge, UK); and anti-borealin (NBP1-89951, dilution of 1:1000) antibody purchased from Novus Biologicals (Centennial, CO, USA). HRP-conjugated secondary antibodies (dilution of 1:10,000) were purchased from Jackson ImmunoResearch Laboratories (West Grove, PA).

Cell synchronization. To arrest cells in the $\mathrm{G}_{1} / \mathrm{S}$ phase, $\mathrm{KB}$ and $\mathrm{KBV} 20 \mathrm{C}$ cells at $30 \%$ confluence were maintained in growth media supplemented with $2 \mathrm{mM}$ thymidine for $18 \mathrm{~h}$. After washing twice with PBS, the cells were switched to fresh growth media for $9 \mathrm{~h}$. Next, $2 \mathrm{mM}$ thymidine was re-added to the culture and cells were treated with it for $15 \mathrm{~h}$. To arrest cells in the mitotic phase, cells at $40 \%$ confluence were incubated with $2 \mathrm{mM}$ thymidine for $24 \mathrm{~h}$. After $24 \mathrm{~h}$, cells were washed twice with PBS and incubated with fresh media for $3 \mathrm{~h}$, followed by addition of and incubation with $100 \mathrm{ng} \mathrm{mL}^{-1}$ nocodazole for $12 \mathrm{~h}$.

Western blot analysis. Cells were lysed using NP-40 lysis buffer $(20 \mathrm{mM}$ Tris- $\mathrm{HCl} \mathrm{pH} 8.0,137 \mathrm{mM} \mathrm{NaCl}$, $10 \%$ glycerol, $1 \%$ non-diet P-40, 2 mM EDTA) supplemented with $1 \times$ protease and phosphatase inhibitor cocktails (Roche, Basel, Switzerland). The protein concentration of the lysate was then quantified using Bradford assay (Bio-Rad, Hercules, CA, USA), according to the manufacturer's instructions. Equal amounts of proteins were subjected to SDS-PAGE and transferred to a PVDF membrane (Millipore, Billerica, MA, USA). The membranes were blocked with $5 \%(\mathrm{w} / \mathrm{v})$ skim milk in TBS containing $0.1 \%$ Tween 20 (TBS-T) for $1 \mathrm{~h}$ and then incubated with the primary antibody overnight at $4{ }^{\circ} \mathrm{C}$. After washing three times with TBS-T, the membrane was incubated with a secondary antibody for $1 \mathrm{~h}$ at room temperature. The bound antibodies were visualized using chemiluminescent detection reagents (Advansta, Menlo Park, CA, USA). The intensity of all protein bands was quantified using image processing software (Image Studio version 5.0, LI-COR Biotechnology, Lincoln, NE).

Quantitative reverse transcription PCR. The cellular RNA was extracted using TRIsure (Bioline, London, UK) and $1 \mu \mathrm{g}$ of total RNA was reverse-transcribed to cDNA using the SensiFAST cDNA synthesis kit (Bioline). P-gp mRNA level was analyzed via quantitative PCR using SensiFAST SYBR No-ROX Kit (Bioline) and Eco Real-Time PCR System (Illumina, San Diego, CA). Data were normalized to transcripts encoding GAPDH or L32. The sequences of primer set for P-gp were 5'-CTTCAGGGTTTCACATTTGGC-3' and 5'-GGTAGT CAATGCTCCAGTGG-3'; for GAPDH were 5'-CTCATGACCACAGTCCATGCCATC-3' and 5'-CTGCTT CACCACCTTCTTGATGTC-3'; for L32 were 5'-CAACATTGGTTATGGAAGCAACA-3' and 5'-TGACGT TGTGGACCAGGAACT- $3^{\prime}$. Reaction parameters were as follows: cDNA synthesis at $37^{\circ} \mathrm{C}$ for $60 \mathrm{~min}$, transcriptase inactivation at $85^{\circ} \mathrm{C}$ for $5 \mathrm{~min}$, and PCR cycling at $95^{\circ} \mathrm{C}$ for $10 \mathrm{~s}, 58^{\circ} \mathrm{C}$ for $20 \mathrm{~s}$, and $72{ }^{\circ} \mathrm{C}$ for $20 \mathrm{~s}(40$ cycles).

Flow cytometry analysis. Synchronized KB and KBV20C cells were washed with cold PBS and then fixed using pre-chilled $70 \%$ ethanol for at least $1 \mathrm{~h}$ on ice. After washing with PBS, the fixed cells were treated with $0.2 \mathrm{mg} \mathrm{mL} \mathrm{m}^{-1} \mathrm{RNase}$ at $37^{\circ} \mathrm{C}$ for $1 \mathrm{~h}$, followed by addition of $10 \mu \mathrm{g} \mathrm{mL} \mathrm{m}^{-1}$ propidium iodide (BD Biosciences, Franklin Lakes, NJ, USA), and finally analyzed on a FACS Calibur system (BD Biosciences) using the FlowJo software.

Immunofluorescence. Cells seeded on coverslips were fixed by incubation with pre-chilled 99\% methanol at $-20^{\circ} \mathrm{C}$ for $30 \mathrm{~min}$. After fixation, cover slips were blocked with PBS-BT (1\% BSA, $0.1 \%$ Triton X-100 in PBS) for $30 \mathrm{~min}$ at room temperature. Subsequently, coverslips were incubated with anti-tubulin antibody diluted in PBS-BT overnight at $4{ }^{\circ} \mathrm{C}$ and then with Alexa Fluor 594-conjugated secondary antibodies for $1 \mathrm{~h}$ at room temperature. After 4,6-diamidino-2-phenylindole (DAPI; Thermo Fisher Scientific, Waltham, MA, USA) staining for 3-5 min, the cells were washed three times with PBS and mounted onto glass slides. Staining was evaluated using a Zeiss 710 immunofluorescence microscope (Carl Zeiss, Oberkochen, Germany) and ZEN software.

Rhodamine 123 uptake assay. Rhodamine 123 uptake assay was performed as previously described ${ }^{22}$. $\mathrm{KB}$ and KBV20C cells were pretreated with verapamil or SPC-160002 for $1 \mathrm{~h}$ and then incubated with $10 \mu \mathrm{M}$ rhodamine 123 (Sigma-Aldrich) for $3 \mathrm{~h}$ under normal culture conditions. After washing with cold PBS, cells were resuspended in PBS just before analysis. Fluorescence intensity of intracellular rhodamine 123 was determined using flow cytometry.

In vitro microtubule polymerization assay. Tubulin Polymerization Kits (Cytoskeleton, Inc., Denver, CO, USA) were used according to the manufacturer's instructions. Briefly, $5 \mu \mathrm{L}$ of vehicle (dimethyl sulfoxide; DMSO) or compound was mixed with porcine tubulin $\left(3 \mathrm{mg} \mathrm{mL}^{-1}\right)$ in a reaction buffer $(80 \mathrm{mM} \mathrm{1,4-pipera-}$ zinediethanesulfonic acid (PIPES), $0.5 \mathrm{mM}$ ethylene glycol-bis( $\beta$-aminoethyl ether)- $N, N, N^{\prime}, N^{\prime}$-tetraacetic acid (EGTA), $1 \mathrm{mM}$ guanosine triphosphate (GTP), $2 \mathrm{mM} \mathrm{MgCl}_{2}, 10 \%$ glycerol, made up to a final volume of $100 \mu \mathrm{L}$ ) in wells of a 96 -well plate. While incubating at $37^{\circ} \mathrm{C}$, the absorbance at $340 \mathrm{~nm}$ was measured every $60 \mathrm{~s}$ for $1 \mathrm{~h}$ using a microplate reader (SpectraMax i3x, Molecular Devices, San Jose, CA, USA).

Separation of tubulin into polymerized and unpolymerized fractions. Whole cell lysates were taken from $60 \mathrm{~mm}$ culture dishes with $250 \mu \mathrm{L}$ of lysis buffer $(10 \mathrm{mM}$ Tris- $\mathrm{HCl} \mathrm{pH} \mathrm{7.4,100} \mathrm{mM} \mathrm{NaCl,} 1 \mathrm{mM}$ EDTA, $1 \mathrm{mM}$ EGTA, $1 \% \mathrm{NP}-40,10 \%$ glycerol) at $4{ }^{\circ} \mathrm{C}$ for $20 \mathrm{~min}$. A centrifuge was used at 13,000 rpm for $10 \mathrm{~min}$ to separate soluble and insoluble fractions of cell lysates. The soluble and insoluble fraction were collected, and the pellet was resuspended in $15 \mu \mathrm{L}$ of lysis buffer and $5 \mu \mathrm{L}$ of $5 \mathrm{X}$ sample buffer $(60 \mathrm{mM}$ Tris- $\mathrm{HCl} \mathrm{pH} 6.8,25 \%$ 
glycerol, 2\% SDS, 5\% 2-mercaptoethanol, 0.1\% bromophenol blue). Supernatant and pellet fractions were then loaded for SDS-PAGE, followed with analysis by western blotting.

CSC sphere culture. The surfaces of culture plates were covered using poly-HEMA (poly-2-hydroxyethyl methacrylate, Sigma-Aldrich) dissolved at a concentration of $5 \mathrm{mg} \mathrm{mL}^{-1}$ in $95 \%$ ethanol. After drying completely, the cells were seeded and incubated with neurosphere-culture media [DMEM/F12 medium (Invitrogen) containing $20 \mathrm{ng} \mathrm{mL}^{-1}$ epidermal growth factor, basic fibroblast growth factor, and B27 neural supplement (Invitrogen), in addition to 100 units $\mathrm{mL}^{-1}$ penicillin/streptomycin]. After 4 days, the enriched primary CSC spheres were dissociated to single cells with $0.5 \mathrm{mg} \mathrm{mL}^{-1}$ Dispase (Thermo Scientific) to generate secondary spheres for measuring drug effect.

CSC sphere-formation inhibition assay. To assess the effect on CCS sphere-forming ability, the cells (1000 cells per well) derived from the primary CSC cultures were re-seeded into poly-HEMA-coated 96-well plate and treated with or without drug. After 4 days, the spheres were fixed in $1 \%$ formalin and the spheres ( $\geq 100 \mu \mathrm{m}$ in diameter) were counted under microscope (Nikon, Japan). For comparison, the cytotoxicity to the cells cultured in the attached condition on the plates in same duration were determined using MTS assay. Culture medium supplemented with $10 \%$ or $1 \%$ FBS was used to minimize the effect of serum proteins in the action of drugs because the defined CSC medium contains minimal proteins.

ALDH assay was performed to quantify putative CSC cells that express high ALDH. After the secondary spheres were cultured with or without SPC-160002 for $48 \mathrm{~h}$, the cells were dissociated and analyzed with Aldeflour assay kit (Stem Cell Technology, Cambridge, MA) followed by flow cytometry. A well-defined ALDH inhibitor, $N, N$-diethylaminobenzaldehyde (DEAB), was used for negative control.

Statistical analysis. All statistical analysis was performed by using GraphPad Prism 8.0. The data are presented as mean \pm SD (standard deviation) from at least three independent experiments as indicated in each figure legend. Comparison between data from two groups was analyzed by using a two tailed unpaired Student's $t$-test for independent samples and $p$ value $<0.05$ were considered statistically significant. ${ }^{*} p<0.05,{ }^{* *} p<0.01$, and ${ }^{* * *} p<0.001$.

Received: 11 December 2020; Accepted: 10 May 2021

Published online: 24 May 2021

\section{References}

1. Brouhard, G. J. \& Rice, L. M. Microtubule dynamics: An interplay of biochemistry and mechanics. Nat. Rev. Mol. Cell Biol. 19, 451-463. https://doi.org/10.1038/s41580-018-0009-y (2018).

2. Muroyama, A. \& Lechler, T. Microtubule organization, dynamics and functions in differentiated cells. Development 144, 3012-3021. https://doi.org/10.1242/dev.153171 (2017).

3. Perez, E. A. Microtubule inhibitors: Differentiating tubulin-inhibiting agents based on mechanisms of action, clinical activity, and resistance. Mol. Cancer Ther. 8, 2086-2095. https://doi.org/10.1158/1535-7163.MCT-09-0366 (2009).

4. Cao, Y. N. et al. Recent advances in microtubule-stabilizing agents. Eur. J. Med. Chem. 143, 806-828. https://doi.org/10.1016/j. ejmech.2017.11.062 (2018)

5. Ganguly, A. \& Cabral, F. New insights into mechanisms of resistance to microtubule inhibitors. Biochim. Biophys. Acta 1816, 164-171. https://doi.org/10.1016/j.bbcan.2011.06.001 (2011).

6. Hunt, J. T. Discovery of ixabepilone. Mol. Cancer Ther. 8, 275-281. https://doi.org/10.1158/1535-7163.MCT-08-0999 (2009).

7. Conlin, A., Fornier, M., Hudis, C., Kar, S. \& Kirkpatrick, P. Ixabepilone. Nat. Rev. Drug Discov. 6, 953-954. https://doi.org/10.1038/ nrd2469 (2007).

8. Cho, Y. \& Kim, Y. K. Cancer stem cells as a potential target to overcome multidrug resistance. Front. Oncol. 10, 764. https://doi. org/10.3389/fonc.2020.00764 (2020).

9. Gottesman, M. M., Fojo, T. \& Bates, S. E. Multidrug resistance in cancer: Role of ATP-dependent transporters. Nat. Rev. Cancer 2, 48-58. https://doi.org/10.1038/nrc706 (2002).

10. Housman, G. et al. Drug resistance in cancer: An overview. Cancers (Basel) 6, 1769-1792. https://doi.org/10.3390/cancers6031769 (2014).

11. Sharom, F. J. The P-glycoprotein multidrug transporter. Essays Biochem. 50, 161-178. https://doi.org/10.1042/bse0500161 (2011).

12. Ambudkar, S. V., Kimchi-Sarfaty, C., Sauna, Z. E. \& Gottesman, M. M. P-glycoprotein: From genomics to mechanism. Oncogene 22, 7468-7485. https://doi.org/10.1038/sj.onc.1206948 (2003).

13. Thomas, H. \& Coley, H. M. Overcoming multidrug resistance in cancer: An update on the clinical strategy of inhibiting p-glycoprotein. Cancer Control 10, 159-165. https://doi.org/10.1177/107327480301000207 (2003).

14. Ganapathi, R. N. \& Ganapathi, M. K. Mechanisms regulating resistance to inhibitors of topoisomerase II. Front. Pharmacol. 4, 89. https://doi.org/10.3389/fphar.2013.00089 (2013).

15. Nanayakkara, A. K. et al. Targeted inhibitors of P-glycoprotein increase chemotherapeutic-induced mortality of multidrug resistant tumor cells. Sci. Rep. 8, 967. https://doi.org/10.1038/s41598-018-19325-x (2018).

16. Callaghan, R., Luk, F. \& Bebawy, M. Inhibition of the multidrug resistance P-glycoprotein: Time for a change of strategy?. Drug Metab. Dispos. 42, 623-631. https://doi.org/10.1124/dmd.113.056176 (2014).

17. Gaspar, A., Matos, M. J., Garrido, J., Uriarte, E. \& Borges, F. Chromone: A valid scaffold in medicinal chemistry. Chem. Rev. 114, 4960-4992. https://doi.org/10.1021/cr400265z (2014).

18. Keri, R. S., Budagumpi, S., Pai, R. K. \& Balakrishna, R. G. Chromones as a privileged scaffold in drug discovery: A review. Eur. J. Med. Chem. 78, 340-374. https://doi.org/10.1016/j.ejmech.2014.03.047 (2014).

19. Feng, Z., Lu, X., Gan, L., Zhang, Q. \& Lin, L. Xanthones, a promising anti-inflammatory scaffold: Structure, activity, and drug likeness analysis. Molecules https://doi.org/10.3390/molecules25030598 (2020).

20. Han, S. H. et al. Synthesis of succinimide-containing chromones, naphthoquinones, and xanthones under Rh(III) catalysis: Evaluation of anticancer activity. J. Org. Chem. 81, 12416-12425. https://doi.org/10.1021/acs.joc.6b02577 (2016). 
21. Kim, S. N. et al. 7-Diethylamino-3(2'-benzoxazolyl)-coumarin is a novel microtubule inhibitor with antimitotic activity in multidrug resistant cancer cells. Biochem. Pharmacol. 77, 1773-1779. https://doi.org/10.1016/j.bcp.2009.03.007 (2009).

22. Hwang, J. W. et al. The synthetic ajoene analog SPA3015 induces apoptotic cell death through crosstalk between NF-kappaB and PPARgamma in multidrug-resistant cancer cells. Food Chem. Toxicol. 96, 35-42. https://doi.org/10.1016/j.fct.2016.07.020 (2016).

23. Wang, F. et al. A positive feedback loop involving Haspin and Aurora B promotes CPC accumulation at centromeres in mitosis. Curr. Biol. 21, 1061-1069. https://doi.org/10.1016/j.cub.2011.05.016 (2011).

24. Carmena, M., Wheelock, M., Funabiki, H. \& Earnshaw, W. C. The chromosomal passenger complex (CPC): From easy rider to the godfather of mitosis. Nat. Rev. Mol. Cell Biol. 13, 789-803. https://doi.org/10.1038/nrm3474 (2012).

25. Vader, G., Medema, R. H. \& Lens, S. M. The chromosomal passenger complex: Guiding Aurora-B through mitosis. J. Cell Biol. 173, 833-837. https://doi.org/10.1083/jcb.200604032 (2006).

26. Kim, S. et al. PRMT6-mediated H3R2me2a guides Aurora B to chromosome arms for proper chromosome segregation. Nat. Commun. 11, 612. https://doi.org/10.1038/s41467-020-14511-w (2020).

27. Bates, D. \& Eastman, A. Microtubule destabilising agents: Far more than just antimitotic anticancer drugs. Br. J. Clin. Pharmacol. 83, 255-268. https://doi.org/10.1111/bcp.13126 (2017).

28. Orr, G. A., Verdier-Pinard, P., McDaid, H. \& Horwitz, S. B. Mechanisms of Taxol resistance related to microtubules. Oncogene 22, 7280-7295. https://doi.org/10.1038/sj.onc.1206934 (2003).

29. Nassar, D. \& Blanpain, C. Cancer stem cells: Basic concepts and therapeutic implications. Annu. Rev. Pathol. 11, 47-76. https:// doi.org/10.1146/annurev-pathol-012615-044438 (2016)

30. Ayob, A. Z. \& Ramasamy, T. S. Cancer stem cells as key drivers of tumour progression. J. Biomed. Sci. 25, 20. https://doi.org/10. 1186/s12929-018-0426-4 (2018).

31. Phi, L. T. H. et al. Cancer stem cells (CSCs) in drug resistance and their therapeutic implications in cancer treatment. Stem Cells Int. 2018, 5416923. https://doi.org/10.1155/2018/5416923 (2018).

32. Nakai, E. et al. Enhanced MDR1 expression and chemoresistance of cancer stem cells derived from glioblastoma. Cancer Invest. 27, 901-908. https://doi.org/10.3109/07357900801946679 (2009).

33. Nakagawa-Goto, K. et al. Triethylated chromones with substituted naphthalenes as tubulin inhibitors. Bioorg. Med. Chem. 24, 6048-6057. https://doi.org/10.1016/j.bmc.2016.09.062 (2016).

34. Ho, C. T. et al. A novel microtubule-disrupting agent induces endoplasmic reticular stress-mediated cell death in human hepatocellular carcinoma cells. PLoS ONE 10, e0136340. https://doi.org/10.1371/journal.pone.0136340 (2015).

35. Luduena, R. F. \& Roach, M. C. Tubulin sulfhydryl groups as probes and targets for antimitotic and antimicrotubule agents. Pharmacol. Ther. 49, 133-152. https://doi.org/10.1016/0163-7258(91)90027-j (1991).

36. Begaye, A. \& Sackett, D. L. Measurement of ligand binding to tubulin by sulfhydryl reactivity. Methods Cell Biol. 95, $391-403$. https://doi.org/10.1016/S0091-679X(10)95021-8 (2010).

\section{Acknowledgements}

This study was supported by a grant from the National Research Foundation of Korea (NRF) and the Korean government (MSIP) [NRF-2018R1A2B2005646 (to Y.K.K), NRF-2020R1A2C3005357 (to I.S.K), and NRF2018R1D1A1A02051170 (to J.W.H.)].

\section{Author contributions}

J.W.H., W.Y.K., S.N.K., I.S.K, and Y.K.K. designed the experiments. M.P., J.W.H., Y.C., J.Y., and S.H. performed the experiments. S.K., S.H.H., and I.S.K. synthesized the compounds. J.W.H., S.N.K., I.S.K., and Y.K.K. analyzed the data and prepared the figures. J.W.H., I.S.K., and Y.K.K. wrote the manuscript.

\section{Competing interests}

The authors declare no competing interests.

\section{Additional information}

Supplementary Information The online version contains supplementary material available at https://doi.org/ 10.1038/s41598-021-90337-w.

Correspondence and requests for materials should be addressed to I.S.K. or Y.K.K.

Reprints and permissions information is available at www.nature.com/reprints.

Publisher's note Springer Nature remains neutral with regard to jurisdictional claims in published maps and institutional affiliations.

Open Access This article is licensed under a Creative Commons Attribution 4.0 International License, which permits use, sharing, adaptation, distribution and reproduction in any medium or format, as long as you give appropriate credit to the original author(s) and the source, provide a link to the Creative Commons licence, and indicate if changes were made. The images or other third party material in this article are included in the article's Creative Commons licence, unless indicated otherwise in a credit line to the material. If material is not included in the article's Creative Commons licence and your intended use is not permitted by statutory regulation or exceeds the permitted use, you will need to obtain permission directly from the copyright holder. To view a copy of this licence, visit http://creativecommons.org/licenses/by/4.0/.

(C) The Author(s) 2021 